\title{
Breeding distribution and population decline of globally threatened Grey-necked Picathartes Picathartes oreas in Mbam Minkom Mountain Forest, southern Cameroon
}

\author{
TAKU AWA II, GUILLAUME DZIKOUK and KEN NORRIS
}

\section{Summary}

The Grey-necked Picathartes Picathartes oreas, considered 'Vulnerable', is an enigmatic grounddwelling bird endemic to the central African equatorial rainforest and belongs to a family of only two species. Its distribution extends to the two Endemic Bird Areas within Cameroon (Guinea Congo forest biome and Cameroon mountain arc) and its population is thought to be in decline throughout its range due to increasing habitat fragmentation and disturbance. During MarchApril 2003 and June and October 2007 we surveyed Grey-necked Picathartes in the north-western region of the Mbam Minkom Mountain Forest. In January-March 2006 we surveyed the entire mountain range and found 90 breeding and 24 potential breeding sites, mostly located on the western slopes. From the complete survey, we estimated the population at 44 breeding individuals. Populations were highest in the north-west region but had apparently declined from 40 breeding individuals in 2003 to 20 in 2007 . This region accounted for $41 \%$ of the entire population on the mountain range during the 2006 survey. The Mbam Minkom/Kala Important Bird Area was designated based on the presence of Grey-necked Picathartes but is under high pressure of imminent destruction from agricultural encroachment and illegal timber exploitation. These results have important implications for decision making in delimiting forest boundaries and core areas for protection in the development of management plans. We suggest possible remedial actions, appropriate repeatable methods for future monitoring and opportunities for community involvement in the management and conservation of the site.

\section{Introduction}

The Grey-necked Picathartes Picathartes oreas (hereafter referred to as GNP), considered globally 'Vulnerable' by the IUCN, is a forest-dependent species with a small, declining and highly fragmented population of just 2,500-10,000 individuals throughout central Africa (BirdLife International 2008). Population declines are probably a combined consequence of habitat fragmentation from advancing agriculture, human disturbance and perhaps other factors like low fertility of eggs, stress due to disturbance (Bian et al. 2006) and competition for nest sites (pers. obs. 2005) contributing to low breeding success. The estimated world population of GNP has been reported at 1 ,000 in Nigeria, $<4$, 000 in Cameroon, $<1$,000 in Gabon, $<500$ in Equatorial Guinea and potentially a few hundred in Congo (Brazzaville). It is known to be declining in all its range states except Gabon and Equatorial Guinea where it is thought to be stable (Bian et al. 2006). This population decline has raised concerns about the species both at the international and national levels. Internationally, a Species Action Plan for the species has been developed (Bian et al. 2006). At national level in Cameroon, the species is listed in Class 'A' of 
protected species, meaning that any form of exploitation is prohibited except with special authorization from the Minister in charge of wildlife.

The GNP is a resident bird endemic to the tropical lowland Guinea-Congo forest basin of Nigeria, Cameroon, Gabon and Equatorial Guinea (Collar and Stuart 1985, Ash 1991). It has recently been reported in Congo-Brazzaville (Mamonekene and Bokandza-Paco 2006) the southernmost locality for the species. Cameroon constitutes the main distribution, where GNP has been recorded in several localities. However most of the localities around Yaounde reported in Collar and Stuart (1985) have been completely deforested and the only known sites at present around Yaounde are Mount Kala and Mount Mbam Minkom which make up the Mbam Minkom/Kala Important Bird Area (IBA), one of Cameroon's 35 IBAs.

For GNP, as for any other threatened species, regular population estimates and information on distribution are essential to determine trends and advise conservation management accordingly. Unfortunately, GNP is difficult to count because of its very shy and elusive nature, and the fact that it inhabits relatively inaccessible mountainous areas in intact closed-canopy rainforests. A few studies have been carried out by Brosset (1965) in Gabon, Tye (1987) and Fotso (1993) in Cameroon, Ash (1991) in Nigeria, and Butynski et al. (1996) in Equatorial Guinea. Other records are from ornithologists who report their field observations. Thus apart from sporadic reporting of locations of GNP colonies in Cameroon, no formal surveys have been carried out at any known site to determine its population status.

This paper therefore presents the first systematic study carried out to determine the current breeding population status and distribution of GNP in the Mbam Minkom Mountain Forest IBA of southern Cameroon and the main threats to the species. This forest is unprotected and is one of 15 IBA sites in Cameroon where the species occurs. We searched for both breeding and potential breeding sites and also assessed the potential of the non-forest matrix to support breeding populations of GNP. This census provides baseline data for future studies and to guide the development of management plans for the area to conserve this vulnerable species in its natural habitat.

\section{Methods}

Study area

The Mbam Minkom Mountain Forest $\left(\mathrm{O}^{\circ} 53^{\prime}\right.$ to $03^{\circ} 59^{\prime} \mathrm{N}$, $\mathrm{O}_{1}{ }^{\circ} 2 \mathrm{O}^{\prime}$ to $\mathrm{O} 11^{\circ} 25^{\prime} \mathrm{E}$ ) lies $35 \mathrm{~km}$ to the north-west of the capital city of Yaounde, Cameroon and covers an area of c. 25,00o ha. The climate is equatorial and described as a characteristic "Yaoundeen" climate marked by four seasons, a minor rainy season from mid-March to June, a minor dry season from July to August, a major rainy season from September to mid November and a major dry season from mid November to mid March (Suchel 1987). Total annual precipitation ranges from 1,000 to 1,750 mm with a mean ambient temperature ranging from 18 to $30^{\circ} \mathrm{C}$. Humidity is high and varies from 70 to $90 \%$. The site is topographically diverse, consisting of rugged, hilly terrain with steepsided valleys and narrow ridge tops. It is the highest of the hills that make up the Yaounde massif and forest ranges between 650 and 1,295 $\mathrm{m}$ with numerous streams and rivers running below closed canopy riparian vegetation. The area has no legal protected status and is a mosaic of intact forest, secondary forest, cocoa plantations and patches of early successional vegetation recovering from slash and burn agriculture. Agricultural encroachment has reduced the amount of forest habitat while illegal timber extraction is reducing the quality of the remaining forest. The west-facing slopes are exposed to the wind and support hygrophilous vegetation while the eastfacing slopes support mesophilous vegetation at the same altitude. This contrasting vegetation on opposing mountainside aspects also shows clear demarcations in vegetation along the altitudinal gradient (Achoundong 1985). At 700-900 $\mathrm{m}$ above sea level is mesophilous forest dominated by Triplochiton scleroxylon and Terminalia superba; at 900-1,000 $\mathrm{m}$ above sea level the forest is hygro-mesophilous forest dominated by Leplaea mayombensis, Cola verticillata, 
Allanblackia gabonensis, Garcinia lucida and Trichilia prieureana; and at 1,100 $\mathrm{m}$ and above, summit forest is dominated by Garcinia elliotii, Allanblackia gabonensis and Cola verticillata.

\section{Location of nest sites}

Searches for breeding sites of GNP were conducted during March-April 2003 and June and October 2007 on the north-western slope of Mbam Minkom Mountain Forest, and in JanuaryMarch 2006 throughout the entire mountain range.

We carried out interviews within all 1o forest fringe village communities for clues on GNP breeding and potential breeding sites, illustrating the bird to villagers with a photograph. Where possible we employed local hunters as guides who proved knowledgeable about the forest and carried out a systematic search of all known rocky outcrops for breeding and potential breeding sites. Our search was targeted on, but not limited to, walks and searches along banks and river valley slopes, as described by Thompson (1993) and Butynski et al. (1996) but with an inspection of all rocky outcrops within the entire forest for the characteristic mud nests. Potential breeding sites referred to rock outcrops within the forest with suitable overhangs for nest attachment but not inhabited by the birds. Suitable overhangs referred to rock faces sufficiently inclined such that they were completely dry with no traces of moisture from the rains during the rainy season.

We recorded the geographic locations of all breeding and potential breeding sites using a handheld Global Positioning System to an accuracy of $10-15 \mathrm{~m}$, and assigned site identification numbers to each breeding and potential breeding site. The geographical coordinates were later mapped onto a digitized map of the study area using ArcGIS 9.

\section{Nest status}

The contents and status of each nest were noted for an estimation of the GNP population. At each breeding site, nests were categorised as active (nest having eggs or nestlings), active last breeding season (recent droppings from the chicks below the nest), undergoing repairs (fresh layer of mud on the weathered rim or other fresh patches), undergoing construction, dormant (no lining in nest), partially dilapidated (portions of nest broken off), completely dilapidated (nest scars on rocks), or abandoned (old remnants of nest covered with moss and lichen). As the 2006 survey was carried out after the breeding period for GNP in Mbam Minkom, there were no active nests with eggs or chicks and our estimates were based on remaining evidence of activity during the previous breeding season. The breeding season for GNP within the region ranges from March to November with peaks in June-July and October (Fotso 1993). As a direct count of birds is not practical, an alternative census method to estimate population size followed Fotso (1993) and Thompson (2004) where each active nest was considered to belong to a pair.

\section{Statistical analyses}

In order to test for proximity of breeding sites to watercourses, the distance of breeding sites to nearby streams/rivers was estimated using a GPS. An equivalent number of random points were generated within the study area using the Hawth's extension tool in ArcGIS 9 and the minimum distance to the nearest stream estimated. A Student's t-test was then carried out to compare the observed data and the random sample.

\section{Results}

\section{Population estimate}

From the 34 nests with signs of breeding activity (Table I) found in the survey of the whole Mbam Minkom range in 2006, 22 showed evidence of breeding during the previous breeding 
Table 1. Nest status at Grey-necked Picathartes breeding sites recorded from January to March 2006 in adjacent forests from fringe villages surrounding the Mbam Minkom massif, Cameroon.

\begin{tabular}{|c|c|c|c|c|c|c|c|c|}
\hline Village & $\begin{array}{l}\text { Active } \\
\text { nests }\end{array}$ & $\begin{array}{l}\text { Active last } \\
\text { breeding } \\
\text { season } \\
(2005)\end{array}$ & $\begin{array}{l}\text { Nests } \\
\text { being } \\
\text { repaired }\end{array}$ & $\begin{array}{l}\text { Nests under } \\
\text { construction }\end{array}$ & $\begin{array}{l}\text { Dormant } \\
\text { nests }\end{array}$ & $\begin{array}{l}\text { Partially } \\
\text { dilapidated } \\
\text { nests }\end{array}$ & $\begin{array}{l}\text { Completely } \\
\text { dilapidated } \\
\text { nests }\end{array}$ & $\begin{array}{l}\text { Abandoned } \\
\text { nests }\end{array}$ \\
\hline Nkolnyada & $\mathrm{o}$ & 1 & $\mathrm{o}$ & $\mathrm{o}$ & 5 & 8 & 5 & $\mathrm{o}$ \\
\hline Nkolfeb & $\mathrm{o}$ & 1 & 1 & 1 & o & 2 & 1 & 1 \\
\hline Nkolakie & $\mathrm{o}$ & 8 & $\mathrm{o}$ & 1 & 13 & 16 & 6 & 3 \\
\hline Nkoljobe & $\mathrm{o}$ & $\mathrm{o}$ & o & o & 4 & 3 & 11 & 2 \\
\hline Ngoas & $\mathrm{o}$ & 5 & 1 & 3 & 14 & 11 & 16 & 7 \\
\hline Ekekam & $\mathrm{o}$ & 1 & $\mathrm{o}$ & o & 5 & 1 & 3 & 1 \\
\hline Ozome III & $\mathrm{o}$ & 1 & 1 & $\mathrm{o}$ & 4 & 2 & 2 & 1 \\
\hline Nye Meyong & o & 5 & 2 & 2 & 6 & 2 & 6 & 5 \\
\hline Metak & $\mathrm{o}$ & o & $\mathrm{o}$ & $\mathrm{o}$ & $\mathrm{o}$ & $\mathrm{o}$ & 3 & $\mathrm{o}$ \\
\hline Nouma & o & o & $\mathrm{o}$ & $\mathrm{o}$ & o & $\mathrm{o}$ & 3 & 1 \\
\hline Total & $\mathrm{o}$ & 22 & 5 & 7 & 51 & 45 & 56 & 21 \\
\hline
\end{tabular}

season; giving an estimated population of 44 breeding individuals for the entire mountain range during 2005. The additional 12 active nests under repair or construction were attributed to birds that would have begun breeding at the start of the 2006 breeding season.

In the north-west part of the forest surveyed in 2003, we had found II active nests (having eggs or nestlings) and nine nests under repair/construction, giving a population estimate of 40 breeding individuals (Table 2). In the 2006 survey in the same area, however, only nine nests were recorded showing evidence of breeding in 2005 , indicating a drop in population to an estimated 18 mature individuals. In 2007 eight active nests and two under repair or construction were recorded, giving a population estimate of 20 breeding individuals (Table 2).

Of the estimated 44 breeding individuals recorded over the whole Mbam Minkom range, 36 $(82 \%)$ were recorded within forests adjacent to only three of the ten fringe villages: Nkolakie (eight active nests), Ngoas (five active nests) and Nye Meyong (five active nests). Despite a total count of 20 nests from nine nest sites in forest adjacent to Nkoljobe, none of the nests was active or under repair or construction.

Sixty-eight per cent (68\%) of the estimated 2006 population was recorded on the western slopes ( 15 active nests) from 65 nest sites compared to the eastern slopes (seven active nests) from a total of 25 nest sites.

Fifty five per cent $(55 \%)$ of the estimated GNP population within the Mbam Minkom mountain range was found to be at the upper altitudinal limits between 951 and 1,162 $\mathrm{m} ; 9 \%$ at $851-950 \mathrm{~m} ; 23 \%$ at $751-850 \mathrm{~m}$, and $14 \%$ at the lowest altitudinal range of $650-750 \mathrm{~m}$. However, considering the vegetation layers along the Mbam Minkom mountain slope, $45 \%$ of the estimated population was above $1,000 \mathrm{~m}$ within the summit forest, $14 \%$ between $900-1,000 \mathrm{~m}$ within the hygro-mesophilous forest and the remaining $41 \%$ below $900 \mathrm{~m}$ within the mesophilous forest.

Table 2. Population trend of Grey-necked Picathartes on the north-western slopes from the fringe villages of Nkolakie and Nkolfeb, Cameroon, during 2003, 2006 and 2007.

\begin{tabular}{llll}
\hline Year & Active nests & Nest under repairs/construction & Estimated breeding population \\
\hline 2003 & 11 & 9 & 40 \\
2006 & 9 & N/A & 18 \\
2007 & 8 & 2 & 20 \\
\hline
\end{tabular}




\section{Distribution of breeding and potential breeding sites}

A total of 90 breeding sites and 24 potential breeding sites were mapped within the entire Mbam Minkom Mountain Forest (Figure I). The 90 sites harboured a total of 207 nests including dilapidated nests, with nest numbers ranging from one to six per breeding site. Most of the breeding sites, (63 out of 90; $71 \%$ ) had only one or two nests while very few breeding sites had high nest numbers: three breeding sites had five nests each and four sites had six nests each (Figure 2).

Nest sites were largely concentrated on the western slopes of the forests that can be accessed from the fringe villages of Nkolakie and Nkolfeb in the north-west and Ngoas and Nkoloman in the south-west (Figure 1). Most breeding sites in the forest near the village of Nkolakie had potentially active nests and were located along river gorges on steep slopes in relatively intact riparian forest. Of the 47 nests from 20 breeding sites mapped within the forest near Nkolakie village, eight had been active during the previous breeding season with one nest under construction or repair and only three appeared apparently abandoned. In contrast, despite the more numerous breeding sites (24) with 53 nests in the south-west of the forest near the peripheral villages of Ngoas and Nkoloman, only five nests had evidence of being active during the previous breeding season while the rest were either dilapidated or abandoned (Table 1 ).

The few nest sites on the eastern side tended to be restricted to the steep slopes towards the mountain ridge. The entire eastern side of the forest was accessed from the villages of Ekekam, Ozom III, Nye Meyong, Metak, and Nouma and had only 25 breeding sites. Eleven were in forest accessed from Nye Meyong, which is one of the settlements within the forest, closer to the middle ridge of the massif. These 11 sites had a total of 28 nests, five of which showed evidence of being active during the previous breeding season. South of the massif towards Ekekam, only one of the 11 nests recorded was active during the previous breeding season. In the north-east towards Metak and Nouma only three breeding sites with six nests (all completely dilapidated) were found. To the extreme north of the massif towards Nkolnyada village, nine breeding sites with 19 nests were recorded but only one had evidence of being active during the previous breeding season (Table 1).

No nest sites were found in farms, fallow land or plantations, although some farms extended close to within $100 \mathrm{~m}$ of some nest sites, especially at the foot of the slopes on the north-western side of the massif. Most of the breeding sites at lower altitude were isolated in forest patches within farmland, connected by corridors of riparian forest. Breeding sites ranged from $150 \mathrm{~m}$ to $3.41 \mathrm{~km}$ from adjacent fringe villages with those closer to the villages in imminent danger of destruction from agricultural encroachment and timber exploitation. On the western slopes, $72 \%$ of nest sites were within $2.5 \mathrm{~km}$ of the fringe villages while on the eastern slopes $80 \%$ of the nest sites were within the same distance range from villages (Figure 3). Considering the entire mountain range, breeding sites ranged from altitudes of 652 to $1,162 \mathrm{~m}$. However, the forest on the eastern slopes had a higher altitudinal range and consequently breeding sites were generally higher on the eastern slopes with lowest breeding site recorded at $794 \mathrm{~m}$ (Figure 4).

Breeding sites were distributed close to streams and rivers with 74 of the 90 breeding sites within $200 \mathrm{~m}$ of a watercourse (Figure 1 ). Of the 16 that were beyond, six had spring sources from beneath the rocks. One breeding site was recorded $900 \mathrm{~m}$ away from a watercourse. Breeding sites were significantly closer to watercourses than expected by chance, with a mean distance of $147.3 \pm 28.77 \mathrm{~m}$ compared to a random sample of sites with a mean distance of $225.8 \pm 21.75 \mathrm{~m}$ $\left(t_{178}=2.18, P=0.031\right.$ (two-tailed) .

\section{Discussion}

\section{Population}

The estimated population of 44 mature individuals of GNP in the Mbam Minkom Mountain Forest is conservative, considering that the survey was carried out outside the breeding season, 


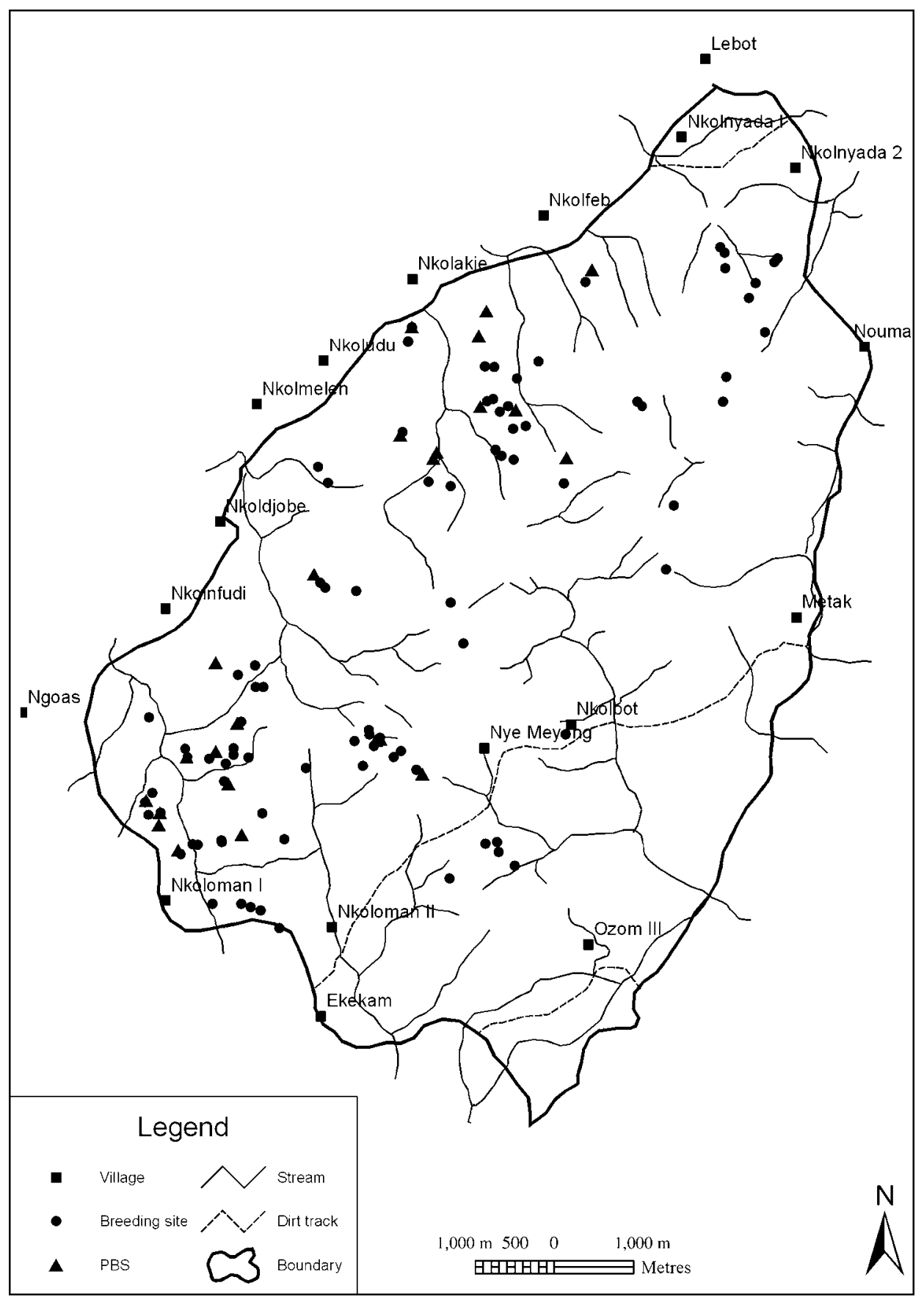

Figure 1. Distribution of Grey-necked Picathartes breeding sites and potential breeding sites (PBS) within the Mbam Minkom Mountain Forest, Cameroon, indicating surrounding fringe villages. 


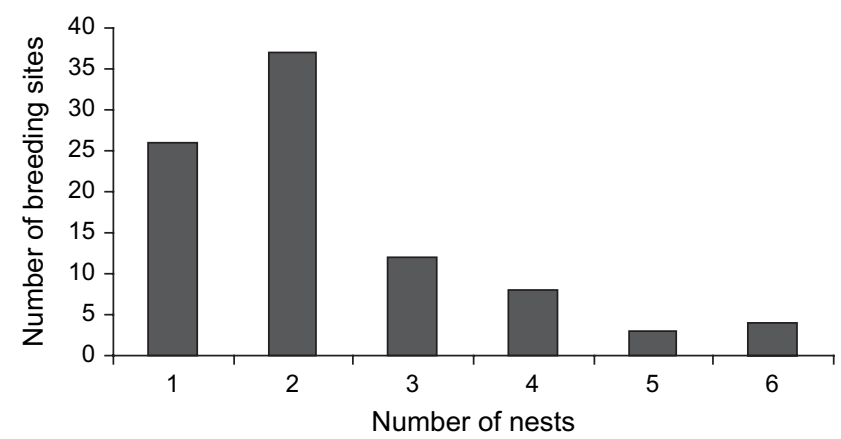

Figure 2. Frequency of nest numbers at breeding sites of Grey-necked Picathartes in the Mbam Minkom Mountain Forest.

which reduces the certainty of identifying nests that were used during the past breeding season. However, results obtained from Nkolakie village were in conformity with direct observations of nests made during the previous breeding season, indicating that the method was reliable. Nevertheless, it is possible that a nest could be used twice by different pairs in a given breeding season, though such double use of nests will not be frequent given the high availability of spare, unused nests at this study site. On only one occasion did we observe the re-use of a nest but in this case it was in an area with limited nest sites where the chicks of a first brood were killed and thrown out by another pair of GNP. One further possible cause of error is that it is not certain if all the mature individuals breed every year. Our estimate therefore represents the minimum figure of adult breeders.

As the birds are very shy, silent and very difficult to encounter within the forest, the indirect method of counting mature individuals from active nest sites is so far the most appropriate. Fotso (1993) used this method and reported an estimated population of only 56 individuals of GNP from the six hills around Yaounde. Also, based on nest numbers, Ash (1991) reported an estimate of 500-1,000 GNP from the various forested areas of south-eastern Nigeria. While this number can still be considered small, it is almost certainly an overestimate, as it was based mostly on estimated nest numbers from hunters who did not do actual counts and probably did not distinguish the status of nests. Moreover, as the proportions of active nests were extrapolated from observations from one site, this could have led to bias if the site visited was of better habitat

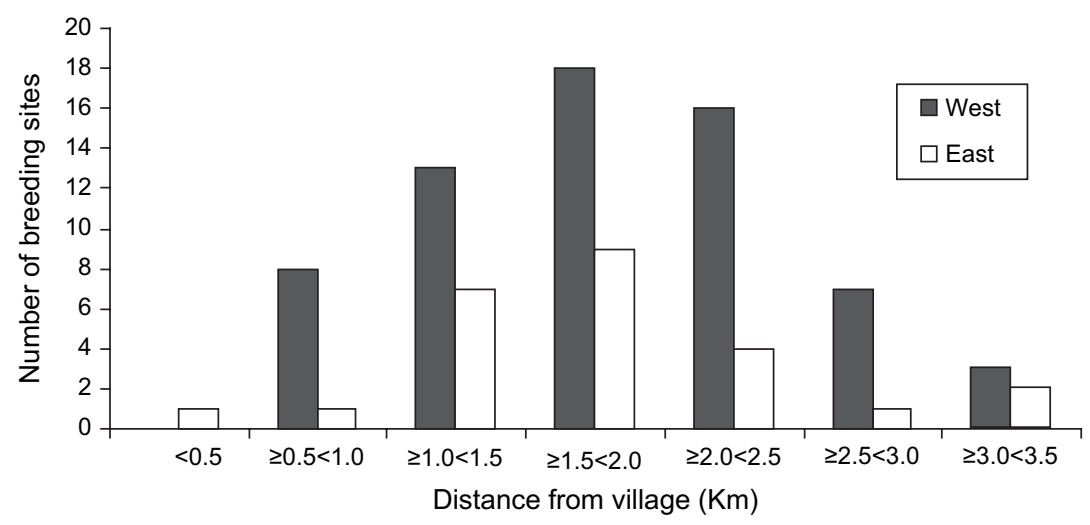

Figure 3. Distance to breeding sites of Grey-necked Picathartes in adjacent forest from fringe villages on the west and east slopes of Mbam Minkom Mountain Forest. 


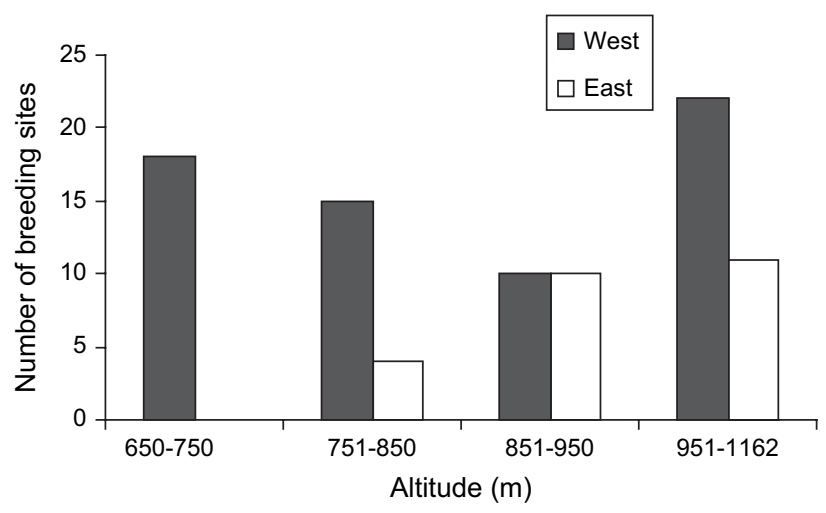

Figure 4. Altitudinal distribution of breeding sites of Grey-necked Picathartes on the west and east slopes of Mbam Minkom Mountain Forest.

quality with more suitable substrates for nesting by GNP. Butynski et al. (1996) from an incomplete survey on Bioko Island, Equatorial Guinea, reported an estimated population of only one or two dozen. Considering the limited numbers reported from actual surveys, current estimates of mature individuals reported by BirdLife International (2008) appears to be an overestimate. Even though it can be argued that new colonies are still being identified from rugged and less accessible areas, a good number of colonies from known historic records around Yaounde (Collar and Stuart 1985) have disappeared as a consequence of effects of deforestation and more recently perhaps from the impact of unsustainable tourism practices. For instance, at Mount Messa, near Yaounde, where Fotso (1993) reported GNP, human settlements now extend high up the hill and there has been extensive deforestation through timber exploitation and farming. No birds were observed during visits to the site in 2006 and no nesting could be possible as the last remaining nest site had been converted into a storage area for planks sawn from illegally exploited timber (pers. obs.). Furthermore, the birds are no longer seen at two of three known sites at Korup NP where tour groups used to go to the see the bird (Jaap van der Waarde, pers. comm. 2007).

The apparent population decline observed from the time series data on the north-western part of Mbam Minkom Mountain Forest could possibly be attributed to the recent introduction and use of chainsaws in illegal timber exploitation. This has brought about major deforestation and damaging effects to the nest sites of GNP, some of which now appear to have been abandoned within the four years since 2003. From the south-western part of the forest from the village of Ngoas with the highest number of breeding sites and nests, only nine (15.79\%) showed signs of activity. This area had suffered massive disturbance from the intense timber exploitation that took place in this part of the forest in the 1980 s (Ebode, pers. comm. 2006). This probably explains why most of the nests appeared abandoned, dormant, partially or completely dilapidated. The present population may be recovering, however, as GNP disperse to newer sites, such as one of the potential breeding sites identified in 2006 where nest construction was observed in 2007 .

\section{Distribution}

Considering the abundance of occupied and potential breeding sites within this study area, The Mbam Minkom range appears to be a stronghold for the GNP whose distribution is probably greatly limited by scarcity of suitable nest sites across its range (Brosset and Erad 1986). According to Tye (1987) they nest colonially where nest sites are limited and this is the case for most of its known locations in Cameroon as well as Gabon, where they have also been reported to be colonial (Brosset 1965). Consequently, even though they have been reported in some larger 
and more extensive intact forests with national protected status, their populations in such sites can be greatly limited by the absence of suitable nest sites. This is evident from the nature of the topography of south-eastern Cameroon down to Gabon and Congo, where the flatter lowland forest offers limited opportunity for rocky outcrops with suitable overhangs.

In the Mbam Minkom range breeding and potential breeding sites were largely concentrated on the steeper western slopes of the mountain ridge, probably due to the availability of suitable rocky substrates that constitute nest sites, especially along watercourses. Rocky outcrops on the eastern side did not generally present suitable overhangs and the eastern area had a gentler gradient towards the adjacent villages, with steep slopes restricted towards the ridge of the massif. In addition, the less steep slopes on the eastern flanks have facilitated agricultural encroachment and human settlements inside the forest at the foot of the mid-ridge. The abrupt slopes on the west and the rocky river/stream gorges appear to be a limiting factor to agricultural encroachment, though this is now occurring as population growth is coupled with the unsustainable practice of slash and burn farming. The complete absence of GNP in farms, fallows or plantations is indicative that they cannot tolerate agricultural encroachment. However, some extensive and continuous more or less intact forest still exists towards the ridge tops, offering the opportunity for protection and management. Altitude in itself is not a limiting factor to the distribution of GNP at our study area as the altitudinal extremes of our study area are within the known altitudinal range of GNP from 45 to 2,100 m (BirdLife International 2008).

\section{Threats}

GNP within the Mbam Minkom Mountain Forest is mainly threatened by agricultural encroachment and illegal timber exploitation. Hunters apparently do not target the bird, and while GNP can accidentally fall prey to traps and snares set for small mammals (Fotso 1993) it is unlikely to be an important cause of mortality. None of the villagers reported any such accidental catch of GNP, nor did we observe any from the numerous traps that we came across during the four years of this study. Nevertheless, traps remain a potential danger and should be avoided within a $300 \mathrm{~m}$ radius around GNP nest sites where birds are known to forage actively during breeding (Brosset 1965, Fotso 1993) or better still at $1 \mathrm{~km}$ from nest sites as GNP occasionally undertake excursions of up to $1.8 \mathrm{~km}$ from the nest during breeding (Taku 2008).

Deforestation intensified while the government was considering the promotion of tourism in Cameroon. Development of Mbam Minkom Mountain Forest as a potential tourist destination led to the introduction of chainsaws in the north-western part in 2004 that were used to cut trees and make planks for construction of a hut at the summit. Chainsaws have now been widely adopted and used to fell trees within the part of the forest that is the stronghold for GNP in the area. As this activity is illegal it can easily be controlled if corruption within the forestry control brigade is checked and the area gazetted for community management. Disturbance from tourism is also a cause for concern if not operated responsibly. As prey delivery rates to nestling GNP peak in the evenings (Taku 2008), human visits in the evenings without measures to minimize disturbance could result in a disproportionate effect on breeding success. While other factors could also be responsible for the population decline in GNP, deforestation and disturbance are plausibly the main causes.

\section{Conclusions and recommendations}

Our results suggest that a decline has occurred in the GNP population in Mbam Minkom Mountain Forest IBA. At present, the population is generally small, isolated and dwindling, with habitat-specific requirements, while human-related activity is pressing strongly on its habitat. Habitat loss and degradation have been increasing at this study area and are likely the same for the entire range distribution. An urgent population census is now required at both national and international levels, which could trigger the reclassification of its threat category by BirdLife 
International and IUCN, though on present evidence we believe that the current conservation status ('Vulnerable') is appropriate. As there is no clear synchrony in the breeding behaviours of GNP, a monitoring scheme for population estimates and trends could be faced with the challenge of having to do repeated surveys during the entire breeding season. Recommended periods are March-April during the start of the breeding season and June-July and October corresponding to the peak breeding periods.

In the interim, we recommend that actions be taken to safeguard the Mbam Minkom Mountain Forest from further deforestation. A workable idea would be to establish a community sanctuary, install a safe viewing regime for GNP to promote ecotourism as an alternative income generating activity for the local communities to reduce pressure and dependence on the forest for subsistence. Some opportunities for collaboration exist as the local communities have already been well sensitized during this survey and are organised as Site Support Groups with the help of the BirdLife International affiliate in Cameroon, the Cameroon Biodiversity Conservation Society. Also the site still harbours some primates including, most importantly, the Western Lowland Gorilla Gorilla gorilla which is of high conservation concern and also a considerable tourist attraction. The mountain range is also a major water catchment for the Yaounde area and has long been classified as a green belt for the capital city of Yaounde. In the management of this IBA, the current distribution of GNP should be considered in the selection of core areas for protection and micro-zoning with multiple use areas established. A core area of least $300 \mathrm{~m}$ with no human activity should be restricted around nest sites of GNP. An area of partial exploitation essentially for ecotourism and sustainable exploitation of non-timber forest products and medicinal plants should be delimited for the entire mountain range at $\mathrm{I} \mathrm{km}$ from the fringe villages, beyond which is designated an area of rational use for sustainable agricultural practice extending to the villages. On the eastern side the $\mathrm{I} \mathrm{km}$ limit should be considered from the new settlement villages of Nye Meyong and Nkolbot. The future of this species in the area may depend on conservation actions to halt further encroachment beyond these limits while promoting sustainable agriculture on the already degraded area close to the villages.

\section{Acknowledgements}

Earthwatch Institute (Europe) and the Felix Trust administered by the University of Reading funded this work. The Cameroon Biodiversity Conservation Society offered logistical support during field work. We are highly indebted to Takuo Jean Michele, Charlie Songken, Willy Lawyer and Bidima Antoine for their invaluable assistance in the field. We are also grateful to the numerous field guides from the different villages, Noah Oyeh Francis, Ewuru Eloundu Pius, Joseph Mbarga, Gabriel Mvondo, Ekani, Nke Martin, Ebode Sebastin, Ekongo Barthelemy, Enama Clement, Jean Marie, Engama Joseph, Essomba Sebastian, Mvondo Stanislus for unmatched field assistance in the search and location of the breeding and potential breeding sites. We are also very thankful to the chiefs of the different fringe villages for their hospitality and for allowing us to carry out this study in their respective villages. Critical comments and suggestions by Malcolm Burgess and two anonymous referees helped to improve the manuscript.

\section{References}

Achoundong, G. (1985) Étude écologique et floristique de la végétation des collines de Yaoundé au-dessus de $1000 \mathrm{~m}$. Thèse de doctorat zè cycle. Yaoundé: Université de Yaoundé.

Ash, J. S. (1991) The Grey-necked Picathartes Picarthartes oreas and Ibadan Malimbe
Malimbe ibadanensis in Nigeria. Bird Conserv. Internatn. 1: 71-82.

Bian, R. M., Awa, T., Ndang'ang, P. K., Fotso, R. C., Hoffmann, D, and Sande, E. (2006) International species action plan for the Grey-necked Picathartes Picathartes oreas. Nairobi, Kenya and Sandy, UK: BirdLife 
International and Royal Society for the Protection of Birds.

BirdLife International. (2008) Species factsheet: Picathartes oreas. Downloaded from http://www.birdlife.org on 19/8/2008.

Brosset, A. (1965) La biologie de Picathartes oreas (sic). Biol. Gabonica 1: 101-115.

Brosset, A. and Erard, C. (1986) Les oiseaux des régions forestières du nord-ouest du Gabon. Ecologie et comportement. Vol 1. Paris: Société Nationale de la Protection de la Nature.

Butynski, T. M., Schaaf, C. D. and Hearn, G. W. (1996) The grey-necked picathartes Picathartes oreas on Bioko Island, Equatorial Guinea. Ostrich 90: 90-93.

Collar, N. J. and Stuart, S. N. (1985) Threatened birds of Africa and related islands. The ICBP/ IUCN red data book. Part I. Cambridge, UK and Gland, Switzerland: ICBP and IUCN.

Fotso, R. C. (1993) Contribution à l'étude de la biologie du Picathartes chauve du Cameroun Picathartes oreas. Proc. Pan- Afr. Orn. Congr. 8: 431-437.
Mamonekene, V. and Bokandza-Paco, F. (2006) Premiere observation du Picatharte $\mathrm{du}$ Cameroun Picathartes oreas au Congo-Brazzaville. Bull. Afr. Bird Club 3: 84 .

Suchel, J. B. (1987) Les climats du Cameroun. Thèse de Doctorat Etat. Bordeaux: Université de Bordeaux III.

Taku, A. II. (2008) The Bio-ecology of Greynecked Picathartes, Picathartes oreas: implications for conservation management. Unpublished PhD Thesis. Reading, UK: University of Reading.

Thompson, H. S. (2004) Behaviour of the White-necked Picathartes Picathartes gymnocephalus, at nest sites prior to breeding. Malimbus 26: 24-30.

Thompson, H. S. (1993) Status of whitenecked picathartes - another reason for the conservation of the Peninsula Forest, Sierra Leone. Oryx 27: 155-158.

Tye, H. (1987) Breeding biology of Picathartes oreas. Le Gerfaut 77: 313-332.

\section{TAKU AWA II*}

Centre for Agri-Environmental Research (CAER), Department of Agriculture, University of Reading, Earley Gate, PO Box 237, Reading RG6 6AR, U.K. and Cameroon Biodiversity Conservation Society, PO Box 3055, Messa, Yaounde, Cameroon.

\section{KEN NORRIS}

Centre for Agri-Environmental Research (CAER), Department of Agriculture, University of Reading, Earley Gate, PO Box 237, Reading RG6 6AR, U.K.

\section{GUILLAUME DZIKOUK}

Cameroon Biodiversity Conservation Society, PO Box 3055, Messa, Yaounde, Cameroon.

${ }^{*}$ Corresponding author; e-mail: takuawa@yahoo.co.uk

Received 22 May 2008; revision accepted 3 November 2008 